\title{
Influence of cultivar and environment on quality of Latin American wheats
}

\author{
Daniel Vázquez ${ }^{\mathrm{a}, *}$, Andrés G. Berger ${ }^{\mathrm{a}}$, Martha Cuniberti ${ }^{\mathrm{b}}$, Carlos Bainotti $^{\mathrm{b}}$, Martha Zavariz de Miranda ${ }^{\mathrm{c}}$, \\ Pedro Luiz Scheeren ${ }^{c}$, Claudio Jobet ${ }^{\mathrm{d}}$, Javier Zúñiga ${ }^{\mathrm{d}}$, Graciela Cabrera ${ }^{\mathrm{e}}$, Rubén Verges ${ }^{\mathrm{a}}$, \\ Roberto Javier Peña ${ }^{f}$
}

a INIA La Estanzuela, Ruta $50 \mathrm{~km}$ 11, Colonia 70000, Uruguay

b INTA Marcos Juárez, CC 21, 2580 Marcos Juárez, Córdoba, Argentina

${ }^{\mathrm{c}}$ Embrapa Wheat, Rodovia BR 285, km 294, Passo Fundo, RS, Brazil

d INIA Carillanca, Km 10, Camino Cajón, Vilcún, Chile

e IPTA, Ruta Mariscal Estigarribia, Km 10.5, San Lorenzo, Paraguay

${ }^{\mathrm{f}}$ CIMMYT, Km. 45, Carretera México-Veracruz, El Batán, Texcoco CP 5613, Mexico

\section{A R T I C L E I N F O}

\section{Article history:}

Received 15 August 2011

Received in revised form

20 March 2012

Accepted 27 March 2012

\section{Keywords:}

Wheat quality

Genotype

Environment

$\mathrm{G} \times \mathrm{E}$ interaction

\begin{abstract}
A B S T R A C T
Wheat consumption is growing, with processors asking for wheat-based products showing better and more consistent quality. Genotype, environment and their interaction $(G \times E)$ play an important role in the final expression of quality attributes. An international research consortium was developed in order to evaluate the magnitude of genotype, environment and $G \times E$ effects on wheat quality of cultivars developed for different agro-ecological zones in Latin America. Genotypes released in Argentina, Brazil, Chile, Mexico, Paraguay and Uruguay, were cultivated in twenty different environments within the participating countries. Each environment was characterized for cultural practices, soil type and climatic conditions. Grain yield and analyses of test weight, protein, ash, gluten, Alveograph, Farinograph, Falling Number, SDS sedimentation and flour color were determined. Allelic variations of puroindolines and glutenins were determined in all the genotypes evaluated. Both puroindoline and gluten protein alleles corresponded to genotypes possessing medium to very good bread making quality. Large variability for most quality attributes evaluated was observed, with wider ranges in quality parameters across environments than among genotypes; even for parameters known to be largely determined by genotype. The importance of growing environment on grain quality was proved, suggesting that breeders' quality objectives should be adapted to the targeted environments.
\end{abstract}

(c) 2012 Elsevier Ltd. All rights reserved.

\section{Introduction}

Wheat (Triticum aestivum L.) consumption is increasing worldwide (USDA, 2011). At the same time, consumer preferences are becoming stricter, forcing processors to use wheat with more specific quality attributes (Cuniberti and Seghezzo, 2010; Peña, 2007). This is particularly relevant in the wheat-producing countries of South America: wheat is the most important source of calories in Argentina, Brazil, Chile and Uruguay, and it is among the main sources in Mexico and Paraguay (FAOSTAT, 2011). In Latin America there are wheat-consuming countries which are either large producers or large importers of wheat, making wheat trade

Abbreviations: $\mathrm{G} \times \mathrm{E}$, genotype by environment interaction; PCA, principal component analysis; PC1, principal component 1; PC2, principal component 2.

* Corresponding author. Tel.: +598 4574 8000; fax: +598 45748012.

E-mail address: dvazquez@inia.org.uy (D. Vázquez). important for the local economies (Seghezzo and Cuniberti, 2010; USDA, 2011). This is one of the reasons why national agricultural research institutes across the region have incorporated wheat breeding programs several decades ago, producing locally adapted bread making quality cultivars.

The modern baking industry requires a high level uniformity of wheat quality to meet the demands of the automated processing facilities they use (Finlay et al., 2007). Achieving the demanded standards of grain quality is complex as it is usually influenced by the genotype, the environment and the complex interaction of genetic and environmental $(\mathrm{G} \times \mathrm{E})$ factors. The understanding of these effects is essential to help breeders to set proper objectives and strategies to develop wheat varieties with high yield potential as well as with specific and consistent quality attributes to meet market needs (Williams et al., 2008). The importance of the effects of genotype, environment and $\mathrm{G} \times \mathrm{E}$ is increasing for breeders, growers, grain traders and end-use processors. 
The perception of environment is ambiguous. Different authors use different concepts. Some may refer to environment as agroecological conditions, others could be more specific by indicating climatic conditions, soil characteristics or technical practices, and others may simply divide them into year effect and location effects (Lacaze and Roumet, 2004; Romagosa et al., 2009; Oelofse et al., 2010).

The concept of bread making quality includes several components that should be considered simultaneously. At the same time, there is a wide variation in the effect of genotype and environment on different components. It is known that certain quality parameters are highly influenced by genetic factors (i.e. hardness is clearly genetically determined) (Carson and Edwards, 2009; Morris, 1998; Wrigley, 2007) while other parameters are highly influenced by environment (i.e. protein content) (Carson and Edwards, 2009; Dencic et al., 2011; Wrigley, 2007). However, the magnitude of the effect of genotype and environment differs among most quality components (Caffe-Treml et al., 2011; Graybosch et al., 1996; Ma et al., 2005; Yong et al., 2004).

While the magnitude of the comparative effects of genotype and environment has been studied by several authors, there is no general consensus about which is more important for most quality characteristics. Dencic et al. (2011) proposed that the relative importance of genetic and environmental effects depends on tested genotypes and environmental conditions. Similarly, Williams et al. (2008) suggested that the amplitude of the variation between environments vs. genotypes influences the observed results, and could be part of the explanation for the different magnitude of genotype, environment and $\mathrm{G} \times \mathrm{E}$ found in several works.

Some studies concluded that genetic influence is the most important. Souza et al. (2004) cultivated seven genotypes in nine environments, concluding that genotype selection is critical, while environmental effects were of secondary importance for the range of environmental conditions used. The wide variability of the genotypes used by Dencic et al. (2011) caused the genetic effect to be dominant.

Other works found that environmental effects prevailed over the genetic ones. Finlay et al. (2007) conducted a Canadian survey, concluding that environmental variation was generally larger than the genetic one, with little or no significant interaction. Environmental factors were also the main effects in a Swedish study which analyzed Falling Number, alpha amylase activities and protein composition (Johansson et al., 2003). Peterson et al. (1998) concluded that variation due to environment was of greater magnitude than for genotype for most Mixograph parameters.

Most authors found that the main effect differs among quality characteristics. Using 19 genotypes grown in 18 American environments, Caffe-Treml et al. (2011) found that genotypes represented the main source of variation for several protein quality characteristics. Environment was the main source of variation for protein quantity, ash content and some dough strength related properties (e.g. Mixograph envelope peak value, bake absorption and dough extensibility values) and $\mathrm{G} \times \mathrm{E}$ interaction was minor for most quality parameters. Other studies concluded that protein content parameters were mostly influenced by environment (Graybosch et al., 1996; Ma et al., 2005; Yong et al., 2004). Additional quality factors mainly depended on genetic effects, including maximum resistance to extension (Ma et al., 2005), Mixograph properties (Yong et al., 2004) and glutenin percentage (Graybosch et al., 1996). Overall, these factors can be grouped as protein quality parameters (Carson and Edwards, 2009), yielding the immediate conclusion that protein quality is mainly affected by genotype. Similar observations were summarized previously by Finney (1985) suggesting that protein "quantity is largely a function of the environment, and quality depends mostly on the wheat variety".

Another approach to study protein quality is to determine the protein composition. Working with 7 cultivars grown in 15 environments, Panozzo and Eagles (2000) concluded that glutenin proportion depended on genotypes and gliadin proportion on environments. This is consistent with the results obtained by Graybosch et al. (1996) using different genotypes and environments. Since glutenins are the key component of gluten strength (Carson and Edwards, 2009), these findings correspond to the influence of genotypes on dough strength mentioned in the previous paragraph.

The market recognizes differences among the Latin American wheats. However, it is not clear if the variability is due to the genotypes released in each region or by the environments where they are grown. In order to reach proper conclusions, genetic and environmental effect studies should be conducted for specific wheat production systems. The objectives of this work were to evaluate the magnitude (and nature) of genotype, environment and their interaction effects on wheat quality, and contribute to understand the reasons why certain regions produce better quality wheats than others.

\section{Materials and methods}

Twenty three genotypes from Argentina (4), Brazil (7), Chile (2), Mexico (4), Paraguay (4) and Uruguay (2) were selected as being representative of local breeding programs (Table 1 ). They were characterized by determining gluten protein using the SDS-PAGE protocol described by Singh and Shepherd (1988) with some modifications indicated by Peña et al. (2004). Hardness characterization included Pina-D1b, Pinb-D1b and Pinb-D1c detection (Gautier et al., 1994; Lillemo and Morris, 2000; Tranquilli et al., 1999) and pearl index determination through infrared spectroscopy.

These genotypes were cultivated in the years 2006, 2007 and 2008 in 20 environments distributed across 9 sites in 6 countries (Table 1). The selected sites represent the variability of the wheatproducing areas. In the South Cone, the South West extreme was Purranque, Chile and the North East one was Brasilia. Altitude varied from less than $50 \mathrm{~m}$ like La Estanzuela (Uruguay) up to over $2200 \mathrm{~m}$ in El Batán, Mexico. Some locations (both Paraguayans, both Uruguayans and Passo Fundo, in South Brazil) are considered highly humid to have ideal conditions for wheat cultivation: they accumulated up to $1000 \mathrm{~mm}$ during the growing season. In these environments, disease pressure is high. Londrina (Brazil) is a quite dry location, with low incidence of diseases and good conditions to produce high quality wheat. Others are considered dry, like Brasilia (Brazil) and Obregón (North Western Mexico), where irrigation is available and full irrigation and different levels of drought stress can be simulated. The environment conditions of Argentina 2008 were of extreme drought in relation to the local averages. The experimental design was in all cases a randomized complete block design (RCBD) with 3 replicates. Cultural practices were performed as recommended at each site with full disease control, adjusting nitrogen fertilization to achieve maximum yield potential and adequate protein content. Environments were fully characterized by cultural practices, soil type and climate conditions. Grain yield was recorded and samples collected for analysis.

Grain protein content, ash content, and test weight were determined with methods $46-12,08-01$, and 55-10, respectively, of the American Association of Cereal Chemists (AACC, 2000). Refined flour was obtained using Bühler Mill (AACC Approved Method 2621A, American Association of Cereal Chemists, 2000) or equivalent. Flour attributes: gluten content, Alveograph parameters, Farinograph parameters, and Falling Number, using AACC methods 3812, 54-30, 54-21, and 56-81B (AACC, 2000), respectively, were measured. SDS sedimentation was measured according to Peña et al. (1990), and flour color with a colorimeter (Minolta Chroma Meter) in the CIE $L^{*} a^{*} b^{*}$ color scale with a D65 illuminant. 
Table 1

List of genotypes and environments of Latin American wheats.

\begin{tabular}{|c|c|c|c|c|}
\hline \# & \multicolumn{3}{|c|}{ Genotype name } & Origin \\
\hline 1 & \multicolumn{3}{|c|}{ BIOINTA 1000} & Argentina \\
\hline 2 & \multicolumn{3}{|c|}{ BIOINTA 1001} & Argentina \\
\hline 3 & \multicolumn{3}{|c|}{ BIOINTA 1002} & Argentina \\
\hline 4 & \multicolumn{3}{|c|}{ BIOINTA 1004} & Argentina \\
\hline 5 & \multicolumn{3}{|c|}{ Embrapa 42} & Brasil \\
\hline 6 & \multicolumn{3}{|c|}{ CD 104} & Brasil \\
\hline 7 & \multicolumn{3}{|l|}{ IPR 85} & Brasil \\
\hline 8 & \multicolumn{3}{|l|}{ Ônix } & Brasil \\
\hline 9 & \multicolumn{3}{|l|}{ BRS 208} & Brasil \\
\hline 10 & \multicolumn{3}{|c|}{ BRS Guabiju } & Brasil \\
\hline 11 & \multicolumn{3}{|c|}{ BRS Guamirim } & Brasil \\
\hline 12 & \multicolumn{3}{|c|}{ PANDORA - INIA } & Chile \\
\hline 13 & \multicolumn{3}{|c|}{ QP3065-01 } & Chile \\
\hline 14 & \multicolumn{3}{|c|}{ Kronstad F04 } & Mexico \\
\hline 15 & \multicolumn{3}{|c|}{ Tollocan F05 } & Mexico \\
\hline 16 & \multicolumn{3}{|c|}{ KABY $/ / 2^{*}$ ALUBUC/BAYA } & Mexico \\
\hline 17 & \multicolumn{3}{|c|}{ Altar $84 /$ Ae. squarrosa (Taus) $/ / \mathrm{OCI} / 3 \ldots{ }^{a}$} & Mexico \\
\hline 18 & \multicolumn{3}{|c|}{ Itapua 40 - Obligado } & Paraguay \\
\hline 19 & \multicolumn{3}{|c|}{ Itapua 50 - Amistad } & Paraguay \\
\hline 20 & \multicolumn{3}{|c|}{ Itapua 65 - Don Valerio } & Paraguay \\
\hline 21 & \multicolumn{3}{|c|}{ IAN 10 - Don Arte } & Paraguay \\
\hline 22 & \multicolumn{3}{|c|}{ INIA Churrinche } & Uruguay \\
\hline 23 & \multicolumn{2}{|c|}{ INIA Tero } & & Uruguay \\
\hline \# & Location & Coordinates & Country & Year \\
\hline 1 & Balcarce & $\mathrm{S} 37^{\circ} 43^{\prime} \mathrm{W} 58^{\circ} 16^{\prime}$ & Argentina & 2008 \\
\hline 2 & Marcos Juárez & $\mathrm{S} 31^{\circ} 50^{\prime} \mathrm{W} 62^{\circ} 00^{\prime}$ & Argentina & 2008 \\
\hline 3 & Sáenz Peña & $\mathrm{S} 26^{\circ} 47^{\prime} \mathrm{W} 60^{\circ} 27^{\prime}$ & Argentina & 2008 \\
\hline 4 & Brasilia & $\mathrm{S} 15^{\circ} 44^{\prime} \mathrm{W} 47^{\circ} 54^{\prime}$ & Brasil & 2007 \\
\hline 5 & Londrina & $\mathrm{S} 23^{\circ} 14^{\prime} \mathrm{W} 51^{\circ} 10^{\prime}$ & Brasil & 2007 \\
\hline 6 & Passo Fundo & $\mathrm{S} 28^{\circ} 14^{\prime} \mathrm{W} 52^{\circ} 22^{\prime}$ & Brasil & 2007 \\
\hline 7 & Carillanca & $\mathrm{S} 38^{\circ} 44^{\prime} \mathrm{W} 72^{\circ} 35^{\prime}$ & Chile & 2006 \\
\hline 8 & Carillanca & $\mathrm{S} 38^{\circ} 44^{\prime} \mathrm{W} 72^{\circ} 35^{\prime}$ & Chile & 2007 \\
\hline 9 & Purranque & $\mathrm{S} 40^{\circ} 54^{\prime} \mathrm{W} 73^{\circ} 10^{\prime}$ & Chile & 2007 \\
\hline 10 & Batán & $\mathrm{N} 19^{\circ} 31^{\prime} \mathrm{W} 98^{\circ} 51^{\prime}$ & Mexico & 2006 \\
\hline 11 & Obregón ${ }^{\mathrm{b}}$ & $\mathrm{N} 27^{\circ} 29^{\prime} \mathrm{W} 109^{\circ} 56^{\prime}$ & Mexico & 2006 \\
\hline 12 & Obregón ${ }^{c}$ & $\mathrm{~N} 27^{\circ} 29^{\prime} \mathrm{W} 109^{\circ} 56^{\prime}$ & Mexico & 2006 \\
\hline 13 & Cria & $\mathrm{S} 27^{\circ} 13^{\prime} \mathrm{W} 55^{\circ} 48^{\prime}$ & Paraguay & 2007 \\
\hline 14 & Cria & $\mathrm{S} 27^{\circ} 13^{\prime} \mathrm{W} 55^{\circ} 48^{\prime}$ & Paraguay & 2008 \\
\hline 15 & Yhovy & $\mathrm{S} 24^{\circ} 15^{\prime} \mathrm{W} 55^{\circ} 36^{\prime}$ & Paraguay & 2007 \\
\hline 16 & Yhovy & $\mathrm{S} 24^{\circ} 15^{\prime} \mathrm{W} 55^{\circ} 36^{\prime}$ & Paraguay & 2008 \\
\hline 17 & La Estanzuela & $\mathrm{S} 34^{\circ} 20^{\prime} \mathrm{W} 57^{\circ} 43^{\prime}$ & Uruguay & 2006 \\
\hline 18 & La Estanzuela & $\mathrm{S} 34^{\circ} 20^{\prime} \mathrm{W} 57^{\circ} 43^{\prime}$ & Uruguay & 2007 \\
\hline 19 & Young & $\mathrm{S} 32^{\circ} 40^{\prime} \mathrm{W} 57^{\circ} 45^{\prime}$ & Uruguay & 2006 \\
\hline 20 & Young & $\mathrm{S} 32^{\circ} 40^{\prime} \mathrm{W} 57^{\circ} 45^{\prime}$ & Uruguay & 2007 \\
\hline
\end{tabular}

a Altar 84/Ae. squarrosa (Taus)//OCI/3/VEE/MJI//2* TUI.

b Irrigated.

c Without irrigation.

Previous analyses (Ceretta and van Eeuwijk, 2008) have demonstrated a greater importance of increasing the number of locations $\times$ years than increasing the number of replicates within each individual experimental site. Given that the main objective of the paper is to have an initial quantification of the variability associated to environment and genotype and not to statistically rank and test differences among locations or genotypes, the inclusion of sites where determinations were done on composite samples (over three replicates) was justified. For consistency in the data, descriptive statistics were calculated from the mean values in the case where replicates were analyzed.

Principal component analysis was carried out using Bayesian PCA with the package pcaMethods of the R statistical software. Descriptive statistics were carried out in $\mathrm{R}$ using standard methods.

\section{Results and discussion}

\subsection{Glutenin and puroindoline alleles}

All analyzed genotypes presented bread making quality alleles in the analyzed loci.
Most genotypes presented Glu-1 alleles commonly associated with good gluten strength and good bread making quality (Table 2). All samples presented either the 1 or the $2^{*}$ subunits, which are the best quality scores of Glu-A1 (Payne et al., 1987; Shewry et al., 2003). Ten of them had the subunit 1 , which has been proposed to have better dough mixing properties than $2^{*}$ (O-Olán et al., 2006). Higher variability was observed in the Glu-B1 locus. The subunit pair $17+18$ has the best quality score (Shewry et al., 2003) and only four of the studied genotypes had this allele. However, most samples had either the pair $7+8$ or $7+9$, both with good quality scores for this locus (Payne et al., 1987). Most genotypes (18 out of 23) had the best Glu-D1c allele for gluten strength $(5+10)$ (Eagles et al., 2006; Payne et al., 1987; Zheng et al., 2009). Overall, the Payne quality score range was from 7 to 10 , with 8 genotypes having the maximum scores.

An interesting variability was observed at the Glu-3 loci with 20 different combinations (Table 2). However, no one had the Glu-B3c allele, associated by Zheng et al. (2009) with inferior dough mixing properties.

The translocation $1 \mathrm{BL} / 1 \mathrm{RS}$ is good for disease resistance and to increase yield; however, the literature is consistent about the negative effects on gluten protein composition and technological properties of bread wheat (Dhaliwal et al., 1987; Fenn et al., 1994; Wieser et al., 2000). This translocation was present in Biointa 1001 from Argentina and four genotypes from Paraguay, which had, on average, weaker doughs than those without it.

All genotypes had Pin $a$ and Pin $b$ allele combinations associated with medium hard to hard endosperm, desirable for high dough water absorption and good bread making quality (Morris, 1998).

\subsection{Descriptive statistics}

Phenotypic correlation coefficients obtained from comparisons among quality parameters confirmed the high quality of the collected data. Grain protein and wet gluten content presented highly significant correlation $(r=0.80, P<0.0001)$, as these parameters are associated with protein quantity. The highly significant correlation between the sedimentation volume and Alveograph $W(r=0.55, P<0.01)$ confirmed that a simple and fast technique like the sedimentation volume is a valuable tool to predict the more expensive Alveograph $W$ parameter. Parameters not related with protein quantity and rheological properties also presented expected relationships; for example, flour color $b^{*}$ parameter was highly correlated with grain ash $(r=0.54, P<0.01)$.

Wide variability was observed among both environments and genotypes for all quality parameters (Table 3 ). As expected, the range was broader among environments than among genotypes for parameters known as highly influenced by environment, such as grain yield (3217-4614 $\mathrm{kg} \mathrm{ha}^{-1}$ and $1498-8726 \mathrm{~kg} \mathrm{ha}^{-1}$ for genotypes and environments, respectively), protein (12.4-14.5\% and 9.4-16.1\%), wet gluten (27.3-39.0\% and $19.1-38.9 \%), L^{*}$ value (90.6-92.1\% and $87.9-93.8 \%)$ and ash content $(1.55-1.83 \%$ and $1.30-1.98 \%)$. It is remarkable that these ranges correspond to environments producing from very poor (e.g. protein of $9.4 \%$ ) to very good quality-related parameters (e.g. protein of $16.1 \%$ ). Higher variability among environments was also indicated by standard deviation values; for example, the standard deviation of grain yield for each environment was $2237 \mathrm{~kg} \mathrm{ha}^{-1}$, while for genotypes was $332 \mathrm{~kg} \mathrm{ha}^{-1}$.

Variability was higher for environments than for genotypes also for protein quality parameters (Table 3), which have been reported to be more dependent on genetics (Graybosch et al., 1996; Ma et al., 2005; Yong et al., 2004). The standard deviation of Alveograph $W$ values was $80 \times 10^{-4} \mathrm{~J}$ for each environment, while for genotypes it was $59 \times 10^{-4} \mathrm{~J}$. More detailed variability can be seen in Fig. 1 . 
Table 2

Glutenin proteins and puroindoline alleles of Latin American wheats.

\begin{tabular}{|c|c|c|c|c|c|c|c|c|c|}
\hline \multirow[t]{2}{*}{ Genotype } & \multicolumn{3}{|l|}{ Glu-1 } & \multicolumn{3}{|l|}{ Glu-3 } & \multirow{2}{*}{$\begin{array}{l}\text { Presence of } 1 \mathrm{~B} / \\
1 \mathrm{R} \text { translocation }\end{array}$} & \multicolumn{2}{|c|}{ Puroindolines } \\
\hline & Glu-A1 & Glu-B1 & Glu-D1 & Glu-A3 & Glu-B3 & Glu-D3 & & $\overline{P i n} a$ & Pin $b$ \\
\hline BIOINTA 1000 & 1 & $7+8$ & $5+10$ & $\mathrm{c}$ & $\mathrm{h}$ & $\mathrm{c}$ & - & $\mathrm{b}$ & - \\
\hline BIOINTA 1001 & 1 & 7 oe +9 & $5+10$ & c & $\mathrm{j}$ & $\mathrm{a}$ & + & $\mathrm{a}$ & $\mathrm{b}$ \\
\hline BIOINTA 1002 & 1 & $7+9$ & $5+10$ & $\mathrm{~d}$ & $\mathrm{~b}$ & $\mathrm{c}$ & - & b & - \\
\hline BIOINTA 1004 & $2^{*}$ & $7^{*}+8$ & $5+10$ & $\mathrm{a}$ & b & $\mathrm{a}$ & - & $\mathrm{a}$ & $\mathrm{b}$ \\
\hline Embrapa 42 & 1 & $17+18$ & $5+10$ & $\mathrm{e}$ & $\mathrm{h}$ & b & - & $\mathrm{a}$ & $\mathrm{b}$ \\
\hline CD 104 & $2^{*}$ & $13+16$ & $5+10$ & $\mathrm{c}$ & $\mathrm{i}$ & $\mathrm{b}$ & - & $\mathrm{b}$ & - \\
\hline IPR 85 & 1 & $17+18$ & $5+10$ & $\mathrm{e}$ & $\mathrm{b}$ & $\mathrm{b}$ & - & $\mathrm{a}$ & - \\
\hline Ônix & $2^{*}$ & $7+9$ & $5+10$ & c & $\mathrm{b}$ & $\mathrm{b}$ & - & $\mathrm{a}$ & - \\
\hline BRS 208 & 1 & $7+9$ & $2+12$ & c & $\mathrm{h}$ & $\mathrm{b}$ & - & $\mathrm{b}$ & - \\
\hline BRS Guabiju & 1 & 7 oe +9 & $2+12$ & c & $\mathrm{g}$ & $\mathrm{b}$ & - & $\mathrm{b}$ & - \\
\hline BRS Guamirim & $2^{*}$ & $7+9$ & $2+12$ & c & $\mathrm{f}$ & $\mathrm{b}$ & - & $\mathrm{b}$ & - \\
\hline PANDORA - INIA & $2^{*}$ & $7+9$ & $2+12$ & c & $\mathrm{h}$ & b & - & $\mathrm{b}$ & - \\
\hline QP3065-01 & $2^{*}$ & $7^{*}$ & $5+10$ & c & $\mathrm{h}$ & $\mathrm{c}$ & - & $\mathrm{b}$ & - \\
\hline Kronstad F04 & $2^{*}$ & $7+9$ & $5+10$ & $\mathrm{c}$ & $\mathrm{h}$ & $\mathrm{a}$ & - & $\mathrm{b}$ & - \\
\hline Tollocan F05 & $2^{*}$ & $17+18$ & $5+10$ & $\mathrm{e}$ & $\mathrm{i}$ & $\mathrm{c}$ & - & $\mathrm{b}$ & - \\
\hline KABY $/ / 2^{*}$ ALUBUC/BAYA & $2^{*}$ & $70 e+8$ & $5+10$ & $\mathrm{e}$ & $\mathrm{i}$ & $\mathrm{b}$ & - & $\mathrm{b}$ & - \\
\hline Altar 84/Ae. squarrosa (Taus) //OCI/3/... & $2^{*}$ & $17+18$ & $5+10$ & $\mathrm{~b}$ & $\mathrm{~d}$ & $\mathrm{a}$ & - & $\mathrm{b}$ & - \\
\hline Itapua 40 - Obligado & $2^{*}$ & $7+9$ & $5+10$ & $\mathrm{c}$ & $\mathrm{j}$ & b & + & $\mathrm{a}$ & $\mathrm{b}$ \\
\hline Itapua 50 - Amistad & 1 & $7+9$ & $5+10$ & $\mathrm{c}$ & $\mathrm{j}$ & $\mathrm{a}$ & + & $\mathrm{a}$ & $\mathrm{b}$ \\
\hline Itapua 65 - Don Valerio & $2^{*}$ & $7+9$ & $5+10$ & $\mathrm{c}$ & $\mathrm{j}$ & $\mathrm{b}$ & + & $\mathrm{b}$ & - \\
\hline IAN 10 - Don Arte & 1 & $7+9$ & $5+10$ & $\mathrm{c}$ & $\mathrm{j}$ & $\mathrm{a}$ & + & $\mathrm{a}$ & $\mathrm{b}$ \\
\hline INIA Churrinche & $2^{*}$ & $7+8$ & $5+10$ & $\mathrm{a}$ & $\mathrm{b}$ & $a$ & - & $\mathrm{a}$ & b \\
\hline INIA Tero & 1 & $7 o e+8$ & $2+12$ & c & $\mathrm{b}$ & c & - & $\mathrm{b}$ & - \\
\hline
\end{tabular}

Similarly, for Farinograph stability it was 6.8 and $10.6 \mathrm{~min}$, respectively.

All genotypes presented acceptable bread making quality in the best environment, even though, it was possible to differentiate genotypes in both good and poor quality environments. For example, all genotypes presented at least one environment with an Alveograph $W$ value over $300 \times 10^{-4} \mathrm{~J}$. The strongest one was the Brazilian variety IPR 85 , with the highest average, as well as maximum and minimum values. In the other extreme, the Chilean line QP3065-01 had the lowest average, maximum and minimum (Fig. 1). However, in the proper environment (\#8, Carrillanca, 2007), the poor quality genotype QP3065-01 presented an Alveograph $W$ value $\left(318 \times 10^{-4} \mathrm{~J}\right)$ higher than the good quality genotype IPR 85 in a bad quality environment $\left(220 \times 10^{-4} \mathrm{~J}\right.$ in Young, 2007).

There was no coincidence between genotypes with the best dough extensional properties and those with the best dough mixing properties. Two Brazilians (IPR 85 and BRS Guabiju) and one Mexican (Kronstad F04) were those with highest $W$ (data not shown). Two of them (BRS Guabiju and Kronstad F04) were also among those with highest sedimentation volume, including the one with highest protein, wet gluten content and extensibility (BRS Guabiju). These genotypes had also good mixing properties, but were not the best. The highest Farinograph stability values corresponded to BioINTA 1004, Altar 84/Ae. squarrosa (Taus)//OCI/3/ VEE/MJI//2*TUI, INIA Churrinche and INIA Tero. The very good quality of the mentioned genotypes is consistent with their glutenin alleles. For example, most of them had the good quality Glu$D 1$ allele $(5+10)$. The only ones that have the poor quality Glu-D1 allele $(2+12)$ are BRS Guabiju and INIA Tero; however, they have the 7 oe +9 allele at the Glu-B1 loci, which has a major impact on dough strength (Butow et al., 2003).

Milling properties measured by independent methods were significantly correlated. For example, among the five genotypes with highest ash content, two also presented the lowest $L^{*}$. Therefore, as expected, those with higher mineral contents tended to be those with darker flours.

Grain protein content is an important quality parameter. It is generally accepted that the higher the protein, the better the quality. This rule is not usual for some Brazilian genotypes. However, in this study, environments that produced wheat grains with higher protein content were not necessarily those of better rheological quality. Environments 14, 18 and 20 had the highest protein contents, while environments 3,14 and 18 had the highest wet gluten percentages (data not shown), both related with protein content. Environments with higher Alveograph $W$ and sedimentation volume were both 2007 Chilean (12 and 13), while those with higher Farinograph stability were 4, 7, 16 and 17.

\subsection{Principal components analysis (PCA)}

The first two principal components explained over $50 \%$ of the total variability (accumulative $R$ square $=0.522$ ), while the first three principal components explained two thirds (accumulative $R$ square $=0.664$ )

The first principal component (PC1) was associated with variables related to protein content. PCA loadings of wet gluten and protein content were 0.77 and 0.63 , respectively. Moreover, PCA loadings of Alveograph $L$ (extensibility) and Alveograph $P / L$ (tenacity/extensibility ratio) were 0.79 and -0.69 , indicating high correlation among the previous variables and these ones. The positive association between protein content and extensibility as well as the negative one between Alveograph $P / L$ and protein quantity estimators has been mentioned before by several authors (Færgestad et al., 2000; Uthayakumaran et al., 1999; Vázquez and Watts, 2004).

The second principal component (PC2) was associated with dough or gluten strength. PCA loadings of Alveograph $W$, Alveograph $P$, sedimentation volume and Farinograph absorption were $0.74,0.72,0.55$ and 0.52 , respectively. It should be noted that although dough strength could be a vague concept (Mailhot and Patton, 1988; Williams et al., 1988; Wooding et al., 1999), three methods using three different principles were highly associated with PC2: Alveograph (extensional properties), Farinograph (dough mixing properties) and sedimentation volume (protein solubility). Besides, two unrelated quality predictors (Falling Number and grain ash content) were also related with PC2 with loadings of 0.55 and 0.60 , respectively.

Physical quality parameters were highly negatively associated with PC3. PCA loading of test weight was -0.69 . The value for grain 
Table 3

Maximum, minimum, average and standard deviation of Latin American wheat quality parameters for: a. Genotypes. b. Environments.

\begin{tabular}{|c|c|c|c|c|}
\hline & Minimum & Maximum & Average & $\begin{array}{l}\text { Standard } \\
\text { deviation }\end{array}$ \\
\hline \multicolumn{5}{|l|}{ a. Genotypes } \\
\hline Yield (kg/ha) & 3217 & 4614 & 3915 & 332 \\
\hline Test weight $(\mathrm{kg} / \mathrm{hl})$ & 74.8 & 80.7 & 77.8 & 1.5 \\
\hline Grain protein $(\%)$ & 12.4 & 14.5 & 13.3 & 0.6 \\
\hline Wet gluten (\%) & 27.3 & 39.0 & 34.2 & 2.7 \\
\hline Alveograph $W\left(\times 10^{-4} \mathrm{~J}\right)$ & 221 & 453 & 332 & 59 \\
\hline Alveograph $P(\mathrm{~mm})$ & 68 & 128 & 100 & 15 \\
\hline Alveograph $L(\mathrm{~mm})$ & 60 & 140 & 104 & 19 \\
\hline Alveograph $P / L$ & 0.7 & 2.8 & 1.2 & 0.5 \\
\hline Farinograph absorption (\%) & 57 & 65 & 61 & 2.0 \\
\hline Farinograph stability (min) & 10 & 34 & 21 & 6.8 \\
\hline Flour color, $L^{*}$ & 90.6 & 92.1 & 91.4 & 0.4 \\
\hline Flour color, $a^{*}$ & -0.81 & 0.08 & -0.44 & 0.27 \\
\hline Flour color, $b^{*}$ & 7.7 & 10.8 & 9.6 & 0.8 \\
\hline Falling number (s) & 337 & 428 & 376 & 21 \\
\hline Sedimentation volume $(\mathrm{ml} / \mathrm{g})$ & 12 & 19 & 16 & 2.2 \\
\hline Grain ash content (\%) & 1.55 & 1.83 & 1.68 & 0.08 \\
\hline \multicolumn{5}{|l|}{ b. Environments } \\
\hline Yield (kg/ha) & 1498 & 8726 & 4343 & 2237 \\
\hline Test weight $(\mathrm{kg} / \mathrm{hl})$ & 70.7 & 84.4 & 77.7 & 3.9 \\
\hline Grain protein (\%) & 9.4 & 16.1 & 13.4 & 1.5 \\
\hline Wet gluten $(\%)$ & 19.1 & 38.9 & 34.3 & 4.5 \\
\hline Alveograph $W\left(\times 10^{-4} \mathrm{~J}\right)$ & 192 & 465 & 343 & 80 \\
\hline Alveograph $P(\mathrm{~mm})$ & 62 & 152 & 104 & 23 \\
\hline Alveograph $L(\mathrm{~mm})$ & 50 & 142 & 101 & 26 \\
\hline Alveograph $P / L$ & 0.6 & 2.7 & 1.3 & 0.7 \\
\hline Farinograph absorption (\%) & 56 & 67 & 61 & 3.5 \\
\hline Farinograph stability (min) & 6 & 43 & 24 & 11.2 \\
\hline Flour color, $L^{*}$ & 87.9 & 93.8 & 90.9 & 1.6 \\
\hline Flour color, $a^{*}$ & -1.36 & 0.12 & -0.57 & 0.44 \\
\hline Flour color, $b^{*}$ & 6.9 & 11.7 & 9.5 & 1.5 \\
\hline Falling number (s) & 277 & 465 & 386 & 61 \\
\hline Sedimentation volume $(\mathrm{ml} / \mathrm{g})$ & 11 & 23 & 16 & 3.5 \\
\hline Grain ash content (\%) & 1.30 & 1.98 & 1.68 & 0.24 \\
\hline
\end{tabular}

yield was -0.52 . Also a color measure (Minolta $a^{*}$ ) had a high loading (0.49).

Fig. 2 shows loading vectors of PC1 and PC2. Protein quantity related parameters were in the same region: high PC1 values. At the same time, gluten strength parameters were close to each other in the high PC2 values. Since for good bread making quality it is necessary to have simultaneously high protein content and high gluten strength, the quarter at the top-right is related to "good quality" and the one at the bottom left is related to "poor quality".

Fig. 3 shows PCA scores for all analyzed samples. Values of the Brazilian genotype BRS Guabiju (\#10) are differentiated in Fig. 3a. In most environments, BRS Guabiju samples had desirable quality, since their scores are in the top-right quarter. It is noticeable that although this genotype is one of the best quality ones (e.g.: among the highest Alveograph $W$ and sedimentation volume), it had some environments with scores out of the best quarter.

The opposite situation is the Paraguayan genotype named Itapúa 40 Obligado (Fig. 3b), with only two samples in the desirable region.

The dispersion is wider for most genotypes than for environments. Fig. 3c shows the scores of the best environment, Carillanca 2007: most samples are at the top-right quarter and none is at the bottom left one. The opposite situation is of the Paraguayan environment CRIA 2007 (3d).

As a consequence, it is proposed that environment was more relevant than genotype to get good quality. This trend was more evident when particular data is observed. All genotypes were able to reach a very good value of Alveograph gluten strength $\left(W=300 \times 10^{-4} \mathrm{~J}\right)$ in the best environment for this particular parameter (Saenz Peña, 2008), but none of them were able to reach
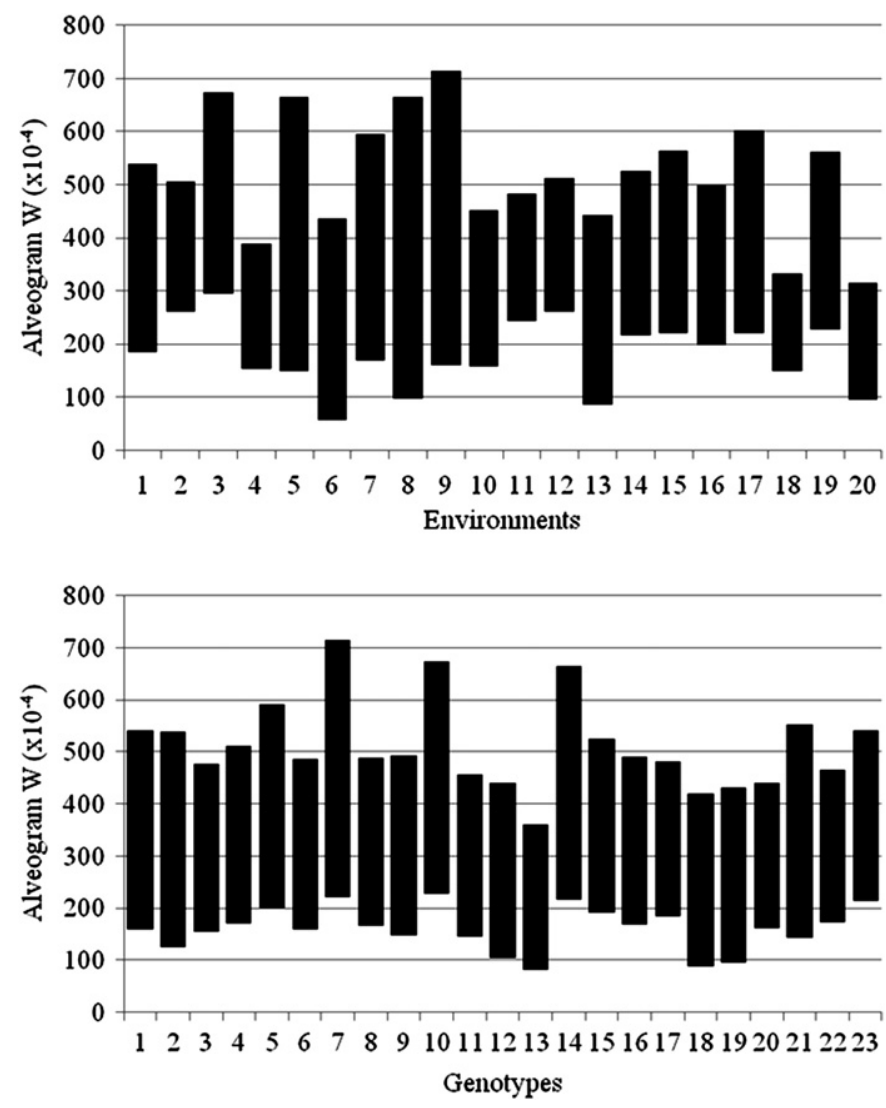

Fig. 1. Alveograph $W\left(\times 10^{-4} \mathrm{~J}\right)$ ranges for environments and genotypes (numbers refer to Table 1) of Latin American wheats.

the same value in the worst environment for Alveograph $W$ (Young, 2007).

Even though the importance of the environmental effect on quality was clear, no evidence was found to prove what caused an environment to have good quality. The data suggests that it was

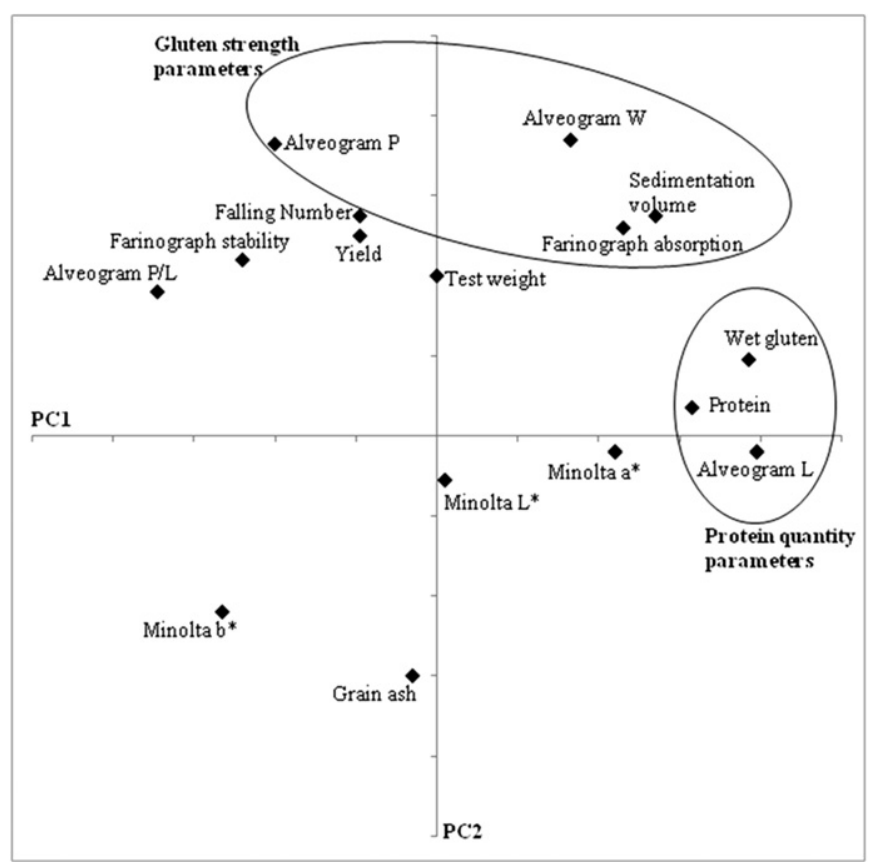

Fig. 2. Principal components analysis: PC1 vs. PC2 loadings. 

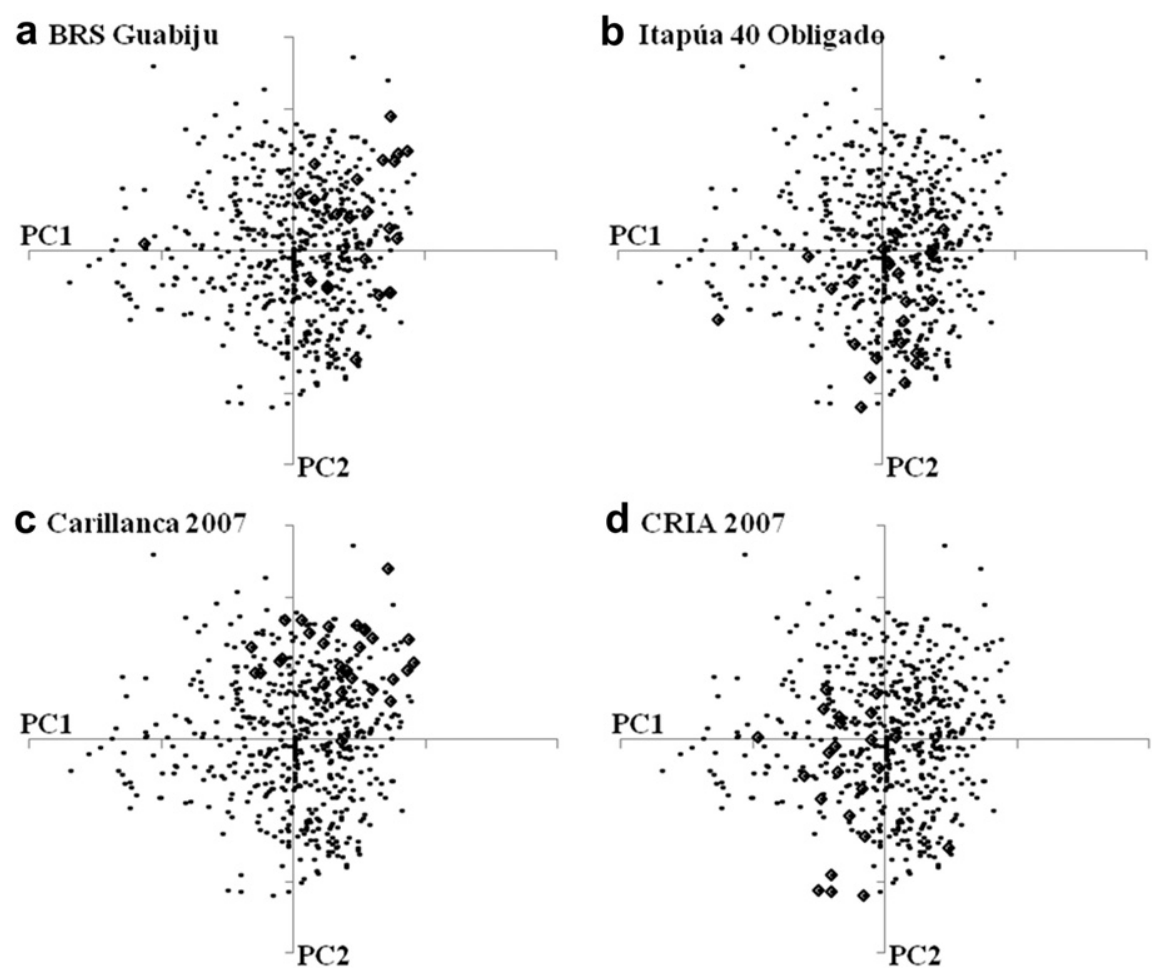

Fig. 3. Principal components analysis: PC1 vs. PC2 individual scores.

not location because some samples grown in the same location in two different years changed their results from "good" to "poor" (data not shown). The significance of climate parameter effects was evaluated without success. As an example, two assays planted in the same location, the same year, differed in water availability (with and without irrigation): their quality was very similar. Temperatures, altitude, latitude and other environmental characteristics were also evaluated, without indicating a clear effect.

\section{Conclusions}

Among the several objectives that breeding programs try to achieve simultaneously, the most important one is high yield. Good quality comes later in the list, although it is recognized that quality improvement is an essential objective to reach markets. In this study, no relationship was found between quality and yield, proving that it is possible to obtain simultaneously high yield and good quality in Latin American environments.

All genotypes had good bread making quality Pin, Glu-1 and Glu-3 alleles. This is expected since all studied genotypes were developed for bread making. However, there was an interesting variability in the Glu-B1, Glu-D1 and Glu-3 loci. In addition, several genotypes presented the $1 \mathrm{~B} / 1 \mathrm{R}$ translocation. Therefore, even if all may reach the minimum end-use requirements, a variability of the genotypes quality was expected.

An important portion of the variability observed in quality was determined by environment. Furthermore, in some environments, not even the best performing genotypes were able to reach acceptable quality levels (Fig. 1). Assuming a minimum value of Alveograph $W$ required for good quality of $320 \times 10^{-} 4 \mathrm{~J}$, all genotypes surpass that value in at least one environment. However, no genotype was able to reach a $W$ of at least $320 \times 10^{-} 4 \mathrm{~J}$ in Young 2007 (environment \#20). Simultaneously, the lowest $W$ at the
Argentinean environment Sáenz Peña 2008 was $294 \times 10^{-} 4 \mathrm{~J}$ (environment \#3).

The importance of environmental effects was demonstrated, but it was not clear what made them cause positive or negative effects on quality. Presumably the number of locations and their distribution was adequate to capture most of the possible variability for the environment effect across locations within two years. The reason why we were not able to identify the major environmental factors showing negative and positive effects on grain yield and processing quality could be the number and/or the nature of the "environments" tested. Twenty environments were used; a large number when the amount of work is considered. However, since we also did consider so many factors (temperature, rain, soil nutrients, etc.), twenty might be a small number for statistical analysis. Further research should include variations of individual factors, or at least a reduced set of factors.

The importance of the environmental effects was observed even for parameters previously reported as more influenced by genotype (Graybosch et al., 1996; Ma et al., 2005; Yong et al., 2004), like the ones related to protein quality. This impact of the environmental effects was reported before for another set of environments (Johansson, 2002; Johansson et al., 2003; Peterson et al., 1998). This observation is very relevant for both breeders and traders. The conclusion for breeders is that if top quality wheat cannot be obtained, it could be due to environmental effects rather than deficiency of the genotype selection. Therefore, in wheat breeding, quality objectives should be set considering both the genotype's intrinsic quality, the environment of the targeted wheat-producing area, and the potential interactions between genotype, environment and crop management. Wheat buyers should realize that a given genotype could produce very different wheat quality in different environments.

It was possible to get good variability in quality even in poor quality environments. These results highlight the importance of 
selecting the best performing genotypes, as an effective measure to improve quality, particularly under generally poor quality environments.

\section{Acknowledgments}

This research was funded by INIA (Spain), CIMMYT, PROCISUR and INIA (Uruguay) and supported by INTA (Argentina), EMBRAPA (Brazil), INIA (Chile) and IAN/DIA (Paraguay). Technical support from wheat breeding and quality group of EEA-INTA Marcos Juárez, Balcarce and Saenz Peña (Argentina), Manoel Carlos Bassói, Júlio César Albrecht, Antônio Sérgio Brizola de Oliveira, Helena de Araújo Andrade, Paulo Rocha de Albuquerque, and Valdir Rizzardo (Embrapa, Brazil), Paola Rathgeb Fuentes, Luisa Vera and Gonzalo Marin (Chile), Orlando Garrido, Fausto Cervantes, Hector Gonzalez, Nayeli Hernandez and Gabriel Posadas (CIMMYT-Mexico), E. Morel, A. Rodriguez, J. Szostak, V. Valdez, E. Altamirano, O. Arce and E. Zayas (Paraguay), José Hernández, Daniela Ramallo, María E. García and Patricia González (Uruguay) was fully appreciated.

\section{References}

American Association of Cereal Chemists, 2000. Approved Methods of the AACC. Methods. 08-01, 26-21A, 38-12, 46-12, 54-21, 54-30, 55-10 and 56-81B, 10th ed. The Association, St. Paul, MN, USA.

Butow, B.J., Ma, W., Gale, K.R. Cornish, G.B., Rampling L, Larroque, O. Morell, M.K., Bekes, F., 2003. Molecular discrimination of Bx7 alleles demonstrates that a highly expressed high-molecular-weight glutenin allele has a major impact on wheat flour dough strength. Theoretical and Applied Genetics 107, 1524-1532.

Caffe-Treml, M., Glover, K.D., Krishnan, P.G., Hareland, G.A., Bondalapati, K.D., Stein, J., 2011. Effect of wheat genotype and environment on relationships between dough extensibility and breadmaking quality. Cereal Chemistry 88, 201-208.

Carson, G.R., Edwards, N.M., 2009. Criteria of wheat and flour quality. In: Khan, K., Shewry, P.R. (Eds.), Wheat: Chemistry and Technology, fourth ed. AACC International, Inc., St. Paul, MN, USA, pp. 97-118.

Ceretta, S., van Eeuwijk, F., 2008. Grain yield variation in malting barley cultivars in Uruguay and its consequences for the design of a trials network. Crop Science 48, 167-180.

Cuniberti, M.B., Seghezzo, M.L., 2010. Developments in wheat and other cereal based local foods in the South America region. In: Taylor, J.R.N., Cracknell, R. (Eds.), ICC Book of Ethnical Cereal-based Foods and Beverages across Continents. ICC, Vienna.

Dencic, S., Mladenov, N., Kobilkjski, B., 2011. Effects of genotype and environment on breadmaking quality in wheat. International Journal of Plant Production 5 , 71-82.

Dhaliwal, A.S., Mares, D.J., Marshall, D.R., 1987. Effect of 1B/1R chromosome translocation on milling and quality characteristics of bread wheats. Cereal Chemistry $64,72-76$.

Eagles, H.A., Cane, K., Eastwood, R.F., Hollamby, G.J., Kuchel, H., Martin, P.J., Cornish, G.B., 2006. Contributions of glutenin and puroindoline genes to grain quality traits in southern Australian wheat breeding programs. Australian Journal of Agricultural Research 57, 179-186.

FAOSTAT, 2011. Food Supply. Crops Primary Equivalent. Published on line at: http:// faostat.fao.org/ (accessed 26.03.11).

Fenn, D., Lukow, O.M., Bushuk, W., Depauw, R.M., 1994. Milling and baking quality of $1 \mathrm{BL} / 1 \mathrm{RS}$ translocation wheats. I. Effects of genotype and environment. Cereal Chemistry 71, 189-195.

Færgestad, E.M., Molteberg, E.L., Magnus, E.M., 2000. Interrelationships of protein composition, protein level, baking process and the characteristics of hearth bread and pan bread. Journal of Cereal Science 31, 309-320.

Finlay, G.J., Bullock, P.R., Sapirstein, H.D., Naeem, H.A., Hussain, A., Angadi, S.V., DePauw, R.M., 2007. Genotypic and environmental variation in grain, flour dough and bread-making characteristics of western Canadian spring wheat. Canadian Journal of Plant Science 87, 679-690.

Finney, K.F., 1985. Experimental breadmaking studies, functional (breadmaking) properties, and related gluten protein fractions. Cereal Foods World 30, 794-801.

Gautier, M.F., Aleman, M.E., Guirao, A., Marion, D., Joudrier, P., 1994. Triticum aestivum puroindolines, two cystine-rich seed proteins: cDNA sequence analysis and developmental gene expression. Plant Molecular Biology 25, 43-57.

Graybosch, R.A., Peterson, C.J., Shelton, D.R., Baezinger, P.S., 1996. Genotypic and environmental modification of wheat flour protein composition in relation to end-use quality. Crop Science 36, 296-300.

Johansson, E., 2002. Effect of two wheat genotypes and Swedish environment on falling number, amylase activities, and protein concentration and composition. Euphytica 126, 143-149.
Johansson, E., Prieto-Linde, M.-L., Kuktaite, R., Andersson, A., Jönsson, J.Ö., 2003. Stability in wheat quality: a utopia or a future possibility. In: Pogna, E.A., Romanò, M., Pogna, N.E., Galterio, G. (Eds.), Proceedings of the Tenth International Wheat Genetics Symposium. Istituto Sperimentale per la Cearlicoltura, Roma, pp. 443-446.

Lacaze, X., Roumet, P., 2004. Environment characterisation for the interpretation of environmental effect and genotype $\times$ environment interaction. Theoretical and Applied Genetics 109, 1632-1640.

Lillemo, M., Morris, C.F., 2000. A leucine to proline mutation in puroindoline b is frequently present in hard wheats from Northern Europe. Theoretical and Applied Genetics 100, 1100-1107.

Ma, W., Appels, R., Békés, F., Larroque, O.R., Morell, M.K., Gale, K.R., 2005. Genetic characterisation of dough rheological properties in a wheat doubled haploid population: additive genetic effects and epistatic interactions. Theoretical and Applied Genetics 111, 410-422.

Mailhot, W.C., Patton, J.C., 1988. Criteria of flour quality. In: Pomeranz, Y. (Ed.) Wheat: Chemistry and Technology. American Association of Cereal Chemists, St. Paul, pp. 131-215.

Morris, C.F., 1998. Genetic determinants of wheat grain quality. In: Slinkard, A.E. (Ed.), Proceedings of the 9th International Wheat Genetics Symposium. University of Saskatchewan, Saskatoon, Canada, pp. 245-253.

Oelofse, R.M., Labuschagne, M.T., van Deventer, C.S., 2010. Influencing factors of sodium dodecyl sulfate sedimentation in bread wheat. Journal of Cereal Science 52,96-99.

O-Olán, M., Espitia-Rangel, E., Molina-Galán, J.D., Peña, R.J., Santacruz Varela, A. Villaseñor-Mir, H.E., 2006. Efecto de diferentes alelos de gluteninas de alto peso molecular sobre las propiedades viscoelásticas de la masa de trigos harineros. Agrociencia 40, 461-469.

Panozzo, J.F., Eagles, H.A., 2000. Cultivar and environmental effects on quality characters in wheat. II. Protein. Australian Journal of Agricultural Research 51, 629-636.

Payne, P.I., Nightingale, M.A., Krattiger, A.F., Holt, L.M., 1987. The relationship between HMW glutenin subunit composition and the bread-making quality of British-grown wheat varieties. Journal of the Science of Food and Agriculture 40, 51-65.

Peterson, C.J., Graybosch, R.A., Shelton, D.R., Baezinger, P.S., 1998. Baking quality of hard winter wheat: response of cultivars to environment in the Great Plains. Euphytica 100, 157-162.

Peña, R.J., 2007. Current and future trends of wheat quality needs. In: Buck, H.T. Nisi, J.E., Salomón, N. (Eds.), Wheat Production in Stressed Environments. Proceedings of the 7th International Wheat Conference. Springer, Dordrecht, The Netherlands, pp. 411-424.

Peña, R.J., Amaya, A., Rajaram, S., Mujeeb-Kazi, A., 1990. Variation in quality characteristics associated with some spring $1 \mathrm{~B} / 1 \mathrm{R}$ translocation wheats. Journal of Cereal Science 12, 105-112.

Peña, R.J., Gonzalez-Santoyo, H., Cervantes, F., 2004. Relationship between Glu-D1 Glu-B3 allelic combinations and bread-making quality-related parameters commonly used in wheat breeding. In: Masci, S., Lafiandra, D. (Eds.), Proceedings of the 8th Gluten Workshop. Viterbo, pp. 156-157.

Romagosa, I., Van Eeuwikj, F.A., Thomas, W.T.B., 2009. Statistical analyses of genotype by environment data. In: Carena, M.J. (Ed.), Cereals. Springer Science, Fargo, ND, USA, pp. 1-39.

Seghezzo, M.L., Cuniberti, M.B., 2010. Wheat marketing and trade situation in Argentina. In: Chung, O.K. (Ed.), Proceedings of the IV International Wheat Quality Conference, Saskatoon, Saskatchewan, Canada, p. 24.

Shewry, P.R., Halford, N.G., Tatham, A.S., Popineau, Y., Lafiandra, D., Belton, P.S. 2003. The high molecular weight subunits of wheat glutenin and their role in determining wheat processing properties. Advances in Food and Nutrition Research 45, 219-302.

Singh, N.K., Shepherd, K.W., 1988. Linkage mapping of genes controlling endosperm storage proteins in wheat. 1 . Genes on the short arms of group 1 chromosomes. Theoretical and Applied Genetics 75, 628-641.

Souza, E.J., Martin, J.M., Guttieri, M.J., O’Brien, K.M., Habernicht, D.K., Lanning, S.P., McLean, R., Carlson, G.R., Talbert, L.E., 2004. Influence of genotype, environment and nitrogen management on spring wheat quality Crop Science 44, 425-432.

Tranquilli, G., Lijavetzky, D., Muzzi, G., Dubcovsky, J., 1999. Genetic and physical characterization of grain texture-related loci in diploid wheat. Molecular and General Genetics 262, 846-850.

USDA, February 2011. Grain: World Market and Trade. Published online at: http:// ffas.usda.gov/grain_arc.asp (accessed 26.03.11).

Uthayakumaran, S., Gras, P.W., Stoddard, F.L., Békés, F., 1999. Effect of varying protein content and glutenin-to-gliadin ration on the functional properties of wheat dough. Cereal Chemistry 76, 389-394.

Vázquez, D., Watts, B.M., 2004. Gluten extensibility: a key factor in Uruguayan wheat quality. In: Lafiandra, D., Masci, S., D'Ovidio, R. (Eds.), The Gluten Proteins. The Royal Society of Chemists, Cambridge, pp. 279-282.

Wieser, H., Kieffer, R., Lelley, T., 2000. The influence of 1B/1R chromosome translocation on gluten protein composition and technological properties of bread wheat. Journal of the Science of Food and Agriculture 80, 1640-1647.

Williams, P.C., Jaby El-Haramein, F., Ortiz-Fereira, G., Srivastava, J.P., 1988. Preliminary observations on the determination of wheat strength by near-infrared reflectance. Cereal Chemistry 65, 109-114.

Williams, R.M., O'Brien, L., Eagles, H.A., Solah, V.A., Jayasena, V., 2008. The influences of genotype, environment, and genotype $\times$ environment interaction on wheat quality. Australian Journal of Agricultural Research 59, 95-111. 
Wooding, A.R., Kavale, S., McRitchie, F., Stoddard, F.L., 1999. Link between mixing requirements and dough strength. Cereal Chemistry 76, 800-806.

Wrigley, C.W., 2007. Mitigating the damaging effects of growth and storage conditions on grain quality. In: Buck, H.T., Nisi, J.E., Salomón, N. (Eds.), Wheat Production in Stress Environments. Developments in Plant Breeding, vol. 12. Springer, Dordrecht, The Netherlands, pp. 425-439.
Yong, Z., Zhonghu, H., Ye, G., Aimin, Z., Van Ginkel, M., 2004. Effect of environment and genotype on bread-making quality of spring-sown spring wheat cultivars in China. Euphytica 139, 75-83.

Zheng, S., Byrne, P.F., Bai, G., Shan, X., Reid, S.D., Haley, Scott D., Seabourn, B.W., 2009. Association analysis reveals effects of wheat glutenin alleles and rye translocations on dough-mixing properties. Journal of Cereal Science 50, 283-290. 